\title{
Evaluation of the extent of wetland birds in District Kaithal, Haryana, India
}

\author{
Rohtash Chand Gupta*, Tirshem Kumar Kaushik and Surjit Kumar \\ Department of Zoology, Kurukshetra University, Kurukshetra (Haryana), INDIA \\ *Corresponding author. E-mail: rohtashchandgupta@rediffmail.com
}

\begin{abstract}
Kaithal District is comprised of $2317 \mathrm{Km}^{2} \mathrm{Sq} . \mathrm{Km}$ area having six blocks Viz.:Kaithal, Kalayat, Pundri, Rajound, Ghula and Siwan located at a distance of $150 \mathrm{Kms}$ from New Delhi toward North West. Its geographical position lies between $29^{\circ} 48^{\prime} 0 \mathrm{~N}$ latitude and between $76^{\circ} 22^{\prime} 60 \mathrm{E}$ longitude. The present studies were carried between 2005-2008 with the help of Zenith Camera and telelens. In all, 63 species of Wetland birds belonging to 10 Orders, 38 genera and 16 families were observed in various village ponds in Kaithal District. Out of 63 species of wetland birds, 31 are winter migratory, 9 local migratory, 3 summers migratory and 20 species are resident birds. Considering IUCN categories, Black lbis (Pseudibis papillosa) which belongs to Biome Restricted Species (BRS) was observed in three blocks viz. Kaithal, Pundri and Rajound of Kaithal district. In addition, Spotted Greenshank (Tringa guttifer) which has been placed in endangered category of IUCN was observed as single individual. But Black Ibis (Pseudibis papillosa) was observed in a group of three to seven. Northern Shoveller (Anas clypeata), which is reportedly coming from Central Russia and Caspian Siberia has been observed in very large groups of 200-250 and virtually spotted in each and every pond in Northern Haryana. Similarly, Northern Pintail (Anas acuta), Common Teal (Anas crecca), Common Pochard (Aythya ferina), Spot-billed Duck (Anas poecilorhyncha), Lesserwhistling Teal (Dendrocygna javanica) were also seen in relatively large groups. Common Pochard (Aythya ferina) is always observed in pure groups floating in the centre of relatively big ponds. In contrast, Gadwall (Anas strepera), Northern Shoveller (Anas clypeata), Northern Pintail (Anas acuta) and Common Teal (Anas crecca), share close proximity with each other in water and are found in mixed groups. Northern Shoveller (Anas clypeata), Bar- headed Goose (Anser indicus) and Northern Pintail (Anas acuta) stay between Octobers to April. Mallard (Anas platyrhynchos) stays in winter for shortest period between December and January. Maximum wetland birds observed in Kaithal District belong to Order Charadriiformes and to family Anatidae of Order Anseriformes. Spotted Greenshank (Tringa guttifer) is the peculiar to Pundri block only, in Kaithal District.
\end{abstract}

Keywords: Migratory Birds, Wetland Birds, Kaithal District, Rural Ponds, Haryana

\section{INTRODUCTION}

Birds do migrate (Aitkin, 1891; Dewar, 1908; Stresemann, 1927-34; Rowan, 1929; Prater, 1931; Bodenslein and Schuz, 1944; Hartley, 1949; Lincoln, 1950;Donald, 1952; Abdulali,1955;Lasiewski,1962;Bisbet, 1963; Collman and Croxall, 1967; Feeny et al, 1968; Pennycuick, 1969;Lucca, 1969; Bailey, 1971;McClure, 1974; Ali, 1996;Drisscoll and Ueta, 2002; Javed et al., 2003 and Bairlein, 2003). Migratory birds come to India as reported by Ali and Ripley, 1968, Birdlife International, 2001, and Kumar et $a l, 2005$. In so far as Haryana is concerned, Wetland birds have been studied at Kurukshetra University (Gupta and Bajaj, 1997, 1998, 1999, 2000, and Gupta et al., 2009). In this paper, attention has been focused on wetland birds of Kaithal District which so far has not been a part of studies by the earlier worker.

It is pertinent to mention here that birds like Arctic Tern, Siberian Crane, Demoiselle Crane, Northern Shoveller, Bar-headed Goose and Eastern Curlews are famous examples in the parleys of the phenomenon of bird migration. Also, Bird like Eastern Golden Plover, Snipe and Bar-tailed Godwit are known for their extremely astonishing long distance non-stop migratory flight. Bird migration is a function of defined and undefined causative functions. For instance, birds migrate to wintering place to avoid extremes of harsh winter and shortage of food in their breeding grounds (Kumar et al., 2005). In India, winter migratory birds come from Srinagar to Trivandum and Ahmedabad to Imphal (Ram, 1978; Ali and Ripley, 1968; Krishna Raju,1978; Khacher, 1986; Pandey, 1989; Sharma and Pandey, 1989; Mohapatra and Rao, 1994; Gandhi and Singh, 1995; Singh,2000;Tak et al., 2001; Kumar and Sivaperuman, 2005 and Kumar et al., 2005).Similarly; birds do come to Haryana state which is lodged in neighborhood of New Delhi (Gupta and Kumar,2009 and Gupta et al., 2009). However, Kaithal District in reference of migratory birds has never been a part of other workers attention and hence the present work.

\section{MATERIALS AND METHODS}

In the present studies, the observations were made in 
Table 1. Checklist of wetland birds in village ponds of Kaithal District in Haryana.

\begin{tabular}{|c|c|c|c|c|c|c|c|c|c|}
\hline S.N & Common Name & Scientific Name & $\begin{array}{c}\text { Res. } \\
\text { Status }\end{array}$ & $*$ GHU & KTH & KAL & PUN & RAJ & SIW \\
\hline \multicolumn{4}{|c|}{ (I) ORDER-PODICIPEDIFORMES } & \multicolumn{6}{|c|}{ (i) FAMILY- PODICIPEDIDAE } \\
\hline 1 & Little Grebe & $\begin{array}{c}\text { Tachybaptaus rufficollis } \\
\text { (Pallas, 1764) }\end{array}$ & $\mathrm{R}$ & $\mathrm{v}$ & $\mathrm{v}$ & $\mathrm{v}$ & $\mathrm{v}$ & $\mathrm{v}$ & $\mathrm{v}$ \\
\hline \multicolumn{4}{|c|}{ (II) ORDER-PELECANIFORMES } & \multicolumn{6}{|c|}{ (i) FAMILY-PHALACROCORACIDAE } \\
\hline 2 & Little Cormorant & $\begin{array}{c}\text { Phalacrocorax niger } \\
\text { (Vieillot, 1817) }\end{array}$ & $\mathrm{R}$ & $\mathrm{v}$ & $\mathrm{v}$ & $\mathrm{v}$ & $\mathrm{v}$ & $\mathrm{v}$ & $\mathrm{v}$ \\
\hline 3 & Indian Shag & $\begin{array}{c}\text { Phalacrocorax } \\
\text { fuscicollis } \\
\text { (Stephens, 1826) }\end{array}$ & $\mathrm{LM}$ & $\mathrm{v}$ & $\mathrm{v}$ & $\mathrm{v}$ & $\mathrm{v}$ & $\mathrm{v}$ & $\mathrm{v}$ \\
\hline 4 & Great Cormorant & $\begin{array}{c}\text { Phalacrocorax carbo } \\
\text { (Linnaeus, 1758) }\end{array}$ & $\mathrm{LM}$ & $\mathrm{v}$ & $\mathrm{v}$ & $\mathrm{v}$ & $\mathrm{v}$ & $\mathrm{v}$ & $\mathrm{v}$ \\
\hline \multicolumn{4}{|c|}{ (III) ORDER-CICONIIFORMES } & \multicolumn{6}{|c|}{ (i) FAMILY-ARDEIDAE } \\
\hline 5 & Little Egret & $\begin{array}{l}\text { Egretta garzetta } \\
\text { (Linnaeus, 1766) }\end{array}$ & $\mathrm{LM}$ & $\mathrm{v}$ & $\mathrm{v}$ & $\mathrm{v}$ & $\mathrm{v}$ & $\mathrm{v}$ & $\mathrm{v}$ \\
\hline 6 & Grey Heron & $\begin{array}{c}\text { Ardea cinerea } \\
\text { (Linnaeus, 1758) }\end{array}$ & WM & $\mathrm{v}$ & $\mathrm{v}$ & $\mathrm{v}$ & $\mathrm{v}$ & $\mathrm{v}$ & $\mathrm{v}$ \\
\hline 7 & Purple Heron & $\begin{array}{l}\text { Ardea purpurea } \\
\text { (Linnaeus, 1766) }\end{array}$ & $\mathrm{LM}$ & $\mathrm{v}$ & $\mathrm{v}$ & $\mathrm{v}$ & $\mathrm{v}$ & $\mathrm{v}$ & $\mathrm{v}$ \\
\hline 8 & Large Egret & $\begin{array}{c}\text { Casmerodius albus } \\
\text { (Linnaeus 1758) }\end{array}$ & $\mathrm{LM}$ & $\mathrm{v}$ & $\mathrm{v}$ & $\mathrm{v}$ & $\mathrm{v}$ & $\mathrm{v}$ & $\mathrm{v}$ \\
\hline 9 & Median Egret & $\begin{array}{c}\text { Mesophoyx intermedia } \\
\text { (Wagler 1829) }\end{array}$ & $\mathrm{LM}$ & $\mathrm{v}$ & $\mathrm{v}$ & $\mathrm{v}$ & $\mathrm{v}$ & $\mathrm{v}$ & $\mathrm{v}$ \\
\hline 10 & Cattle Egret & $\begin{array}{c}\text { Bubulcus ibis } \\
\text { (Linnaeus, 1758) }\end{array}$ & $\mathrm{R}$ & $\mathrm{v}$ & $\mathrm{v}$ & $\mathrm{v}$ & $\mathrm{v}$ & $\mathrm{v}$ & $\mathrm{v}$ \\
\hline 11 & Indian Pond Heron & $\begin{array}{c}\text { Ardeola grayii } \\
\text { (Sykes, 1832) }\end{array}$ & $\mathrm{R}$ & $\mathrm{v}$ & $\mathrm{v}$ & $\mathrm{v}$ & $\mathrm{v}$ & $\mathrm{v}$ & $\mathrm{v}$ \\
\hline 12 & $\begin{array}{l}\text { Black-crowned } \\
\text { Night Heron }\end{array}$ & $\begin{array}{c}\text { Nycticorax nycticorax } \\
\text { (Linnaeus,1758) }\end{array}$ & $\mathrm{R}$ & $\mathrm{v}$ & $\mathrm{v}$ & $\mathrm{v}$ & $\mathrm{v}$ & $\mathrm{v}$ & $\mathrm{v}$ \\
\hline & & & & \multicolumn{6}{|c|}{ (iii) FAMILY-THRESKIORNITHIDAE } \\
\hline 13 & Glossy Ibis & $\begin{array}{c}\text { Plegadis falcinellus } \\
\text { (Linnaeus, 1766) }\end{array}$ & $\mathrm{LM}$ & $\mathrm{X}$ & $\mathrm{X}$ & $\mathrm{X}$ & $\mathrm{v}$ & $\mathrm{X}$ & $\mathrm{X}$ \\
\hline 14 & Black Ibis & $\begin{array}{l}\text { Pseudibis papillosa } \\
\text { (Temminck, 1824) }\end{array}$ & $\mathrm{R}$ & $\mathrm{X}$ & $\mathrm{v}$ & $\mathrm{X}$ & $\mathrm{v}$ & $\mathrm{v}$ & $\mathrm{X}$ \\
\hline \multicolumn{4}{|c|}{ (IV) ORDER-ANSERIFORMES } & \multicolumn{6}{|c|}{ (i) FAMILY- ANATIDAE } \\
\hline 15 & $\begin{array}{l}\text { Large Whistling- } \\
\text { Duck }\end{array}$ & $\begin{array}{c}\text { Dendrocygna bicolor } \\
\text { (Vieillot, 1816) }\end{array}$ & WM & $\mathrm{v}$ & $\mathrm{v}$ & $\mathrm{v}$ & $\mathrm{v}$ & $\mathrm{v}$ & $\mathrm{V}$ \\
\hline 16 & Greylag Goose & $\begin{array}{c}\text { Anser anser } \\
\text { (Linnaeus, 1758) }\end{array}$ & WM & $\mathrm{v}$ & $\mathrm{v}$ & $\mathrm{v}$ & $\mathrm{V}$ & $\mathrm{v}$ & $\mathrm{v}$ \\
\hline
\end{tabular}


Table 1. Continued..

\begin{tabular}{|c|c|c|c|c|c|c|c|c|c|}
\hline 17 & $\begin{array}{l}\text { Lesser Whistling } \\
\text { duck }\end{array}$ & $\begin{array}{c}\text { Dendrocygna javanica } \\
\text { (Horsfield, 1821) }\end{array}$ & $\mathrm{SM}$ & $\mathrm{v}$ & $\mathrm{v}$ & $\mathrm{v}$ & $\mathrm{v}$ & $\mathrm{v}$ & $\mathrm{v}$ \\
\hline 18 & Bar-headed Goose & $\begin{array}{l}\text { Anser indicus } \\
\text { (Latham,1790) }\end{array}$ & WM & $\mathrm{v}$ & $\mathrm{v}$ & $\mathrm{v}$ & $\mathrm{v}$ & $\mathrm{v}$ & $\mathrm{V}$ \\
\hline 19 & Comb Duck & $\begin{array}{l}\text { Sarkidiornis melanotos } \\
\text { (Pennant, 1769) }\end{array}$ & $\mathrm{SM}$ & $\mathrm{v}$ & $\mathrm{v}$ & $\mathrm{v}$ & $\mathrm{v}$ & $\mathrm{v}$ & $\mathrm{v}$ \\
\hline 20 & Gadwall & $\begin{array}{c}\text { Anas strepera } \\
\text { (Linnaeus, 1758) }\end{array}$ & WM & $\mathrm{v}$ & $\mathrm{v}$ & $\mathrm{v}$ & $\mathrm{v}$ & $\mathrm{v}$ & $\mathrm{v}$ \\
\hline 21 & Eurasian Wigeon & $\begin{array}{l}\text { Anas penelope } \\
\text { (Linnaeus, 1758) }\end{array}$ & WM & $\mathrm{X}$ & $\mathrm{v}$ & $\mathrm{v}$ & $\mathrm{v}$ & $\mathrm{v}$ & $\mathrm{X}$ \\
\hline 22 & Mallard & $\begin{array}{c}\text { Anas platyrhynchos } \\
\text { (Linnaeus, 1758) }\end{array}$ & WM & $\mathrm{X}$ & $\mathrm{X}$ & $\mathrm{v}$ & $\mathrm{v}$ & $\mathrm{v}$ & $\mathrm{X}$ \\
\hline 23 & Spot-billed Duck & $\begin{array}{l}\text { Anas poecilorhyncha } \\
\text { (J.R. Forester, 1781) }\end{array}$ & WM & $\mathrm{v}$ & $\mathrm{v}$ & $\mathrm{v}$ & $\mathrm{v}$ & $\mathrm{v}$ & $\mathrm{v}$ \\
\hline 24 & Northern Shoveller & $\begin{array}{c}\text { Anas Clypeata } \\
\text { (Linnaeus, 1758) }\end{array}$ & WM & $\mathrm{v}$ & $\mathrm{v}$ & $\mathrm{v}$ & $\mathrm{v}$ & $\mathrm{v}$ & $\mathrm{v}$ \\
\hline 25 & Northern Pintail & $\begin{array}{c}\text { Anas acuta } \\
\text { (Linnaeus, 1758) }\end{array}$ & WM & $\mathrm{v}$ & $\mathrm{v}$ & $\mathrm{v}$ & $\mathrm{v}$ & $\mathrm{v}$ & $\mathrm{V}$ \\
\hline 26 & Garganey & $\begin{array}{l}\text { Anas querquedula } \\
\text { (Linnaeus, 1758) }\end{array}$ & WM & $\mathrm{X}$ & $\mathrm{v}$ & $\mathrm{v}$ & $\mathrm{v}$ & $\mathrm{v}$ & $\mathrm{X}$ \\
\hline 27 & Common Teal & $\begin{array}{c}\text { Anas Crecca } \\
\text { (Linnaeus, 1758) }\end{array}$ & WM & $\mathrm{v}$ & $\mathrm{v}$ & $\mathrm{v}$ & $\mathrm{v}$ & $\mathrm{v}$ & $\mathrm{v}$ \\
\hline 28 & $\begin{array}{l}\text { Common } \\
\text { Pochard }\end{array}$ & $\begin{array}{c}\text { Aythya ferina } \\
\text { (Linnaeus, 1758) }\end{array}$ & WM & $\mathrm{v}$ & $\mathrm{v}$ & $\mathrm{v}$ & $\mathrm{v}$ & $\mathrm{v}$ & $\mathrm{v}$ \\
\hline$(\mathbf{V})$ & DER-GRUIFORM & & & (i) FAMII & LLI & & & & \\
\hline 29 & $\begin{array}{l}\text { White-breasted } \\
\text { Waterhen }\end{array}$ & $\begin{array}{c}\text { Amaurornis } \\
\text { phoenicurus } \\
\text { (Pennant, 1769) }\end{array}$ & $\mathrm{R}$ & $\mathrm{v}$ & $\mathrm{v}$ & $\mathrm{v}$ & $\mathrm{v}$ & $\mathrm{v}$ & $\mathrm{v}$ \\
\hline 30 & Purple Moorhen & $\begin{array}{c}\text { Porphyrio porphyrio } \\
\text { (Linnaeus, 1758) }\end{array}$ & $\mathrm{R}$ & $\mathrm{v}$ & $\mathrm{v}$ & $\mathrm{v}$ & $\mathrm{V}$ & $\mathrm{v}$ & $\mathrm{V}$ \\
\hline 31 & Common Moorhen & $\begin{array}{c}\text { Gallinula chloropus } \\
\text { (Linnaeus, 1758) }\end{array}$ & LM & $\mathrm{V}$ & $\mathrm{V}$ & $\mathrm{v}$ & $\mathrm{V}$ & $\mathrm{v}$ & $\mathrm{V}$ \\
\hline 32 & Common Coot & $\begin{array}{c}\text { Fulica atra } \\
\text { (Linnaeus, 1758) }\end{array}$ & WM & $\mathrm{V}$ & $\mathrm{v}$ & $\mathrm{v}$ & $\mathrm{V}$ & $\mathrm{v}$ & $\mathrm{V}$ \\
\hline \multicolumn{4}{|c|}{ (VI) ORDER-CHARADRIIFORMES } & \multicolumn{6}{|c|}{ (i) FAMILY - JACANIDAE } \\
\hline 33 & $\begin{array}{c}\text { Pheasant-tailed } \\
\text { Jacana }\end{array}$ & $\begin{array}{c}\text { Hydrophasianus } \\
\text { chirurgus } \\
\text { (Scopoli, 1786) }\end{array}$ & $\mathrm{SM}$ & $\mathrm{V}$ & $\mathrm{V}$ & $\mathrm{v}$ & $\mathrm{V}$ & $\mathrm{v}$ & $\mathrm{V}$ \\
\hline
\end{tabular}


Table 1. Continued..

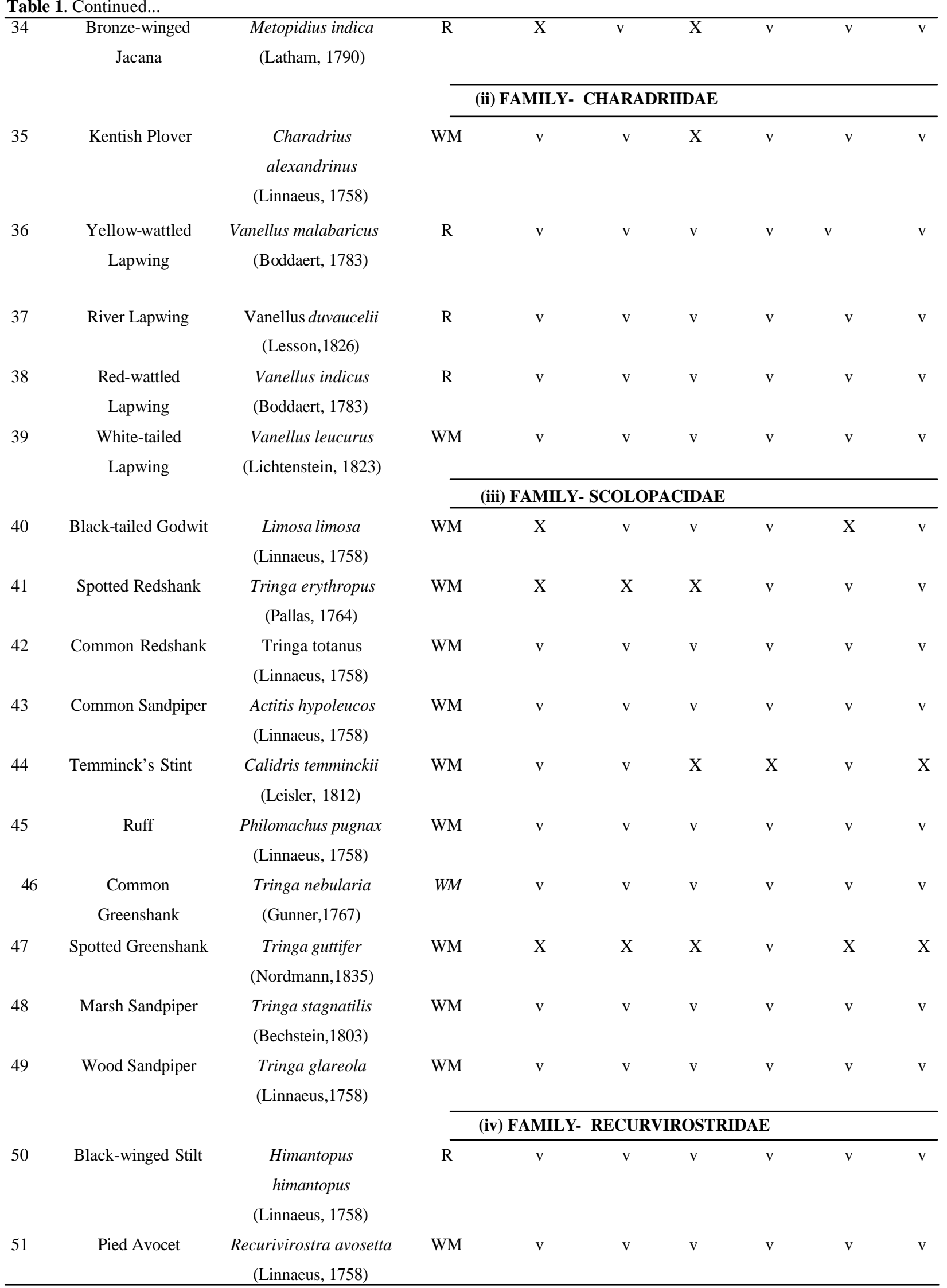


Table 1. Continued...

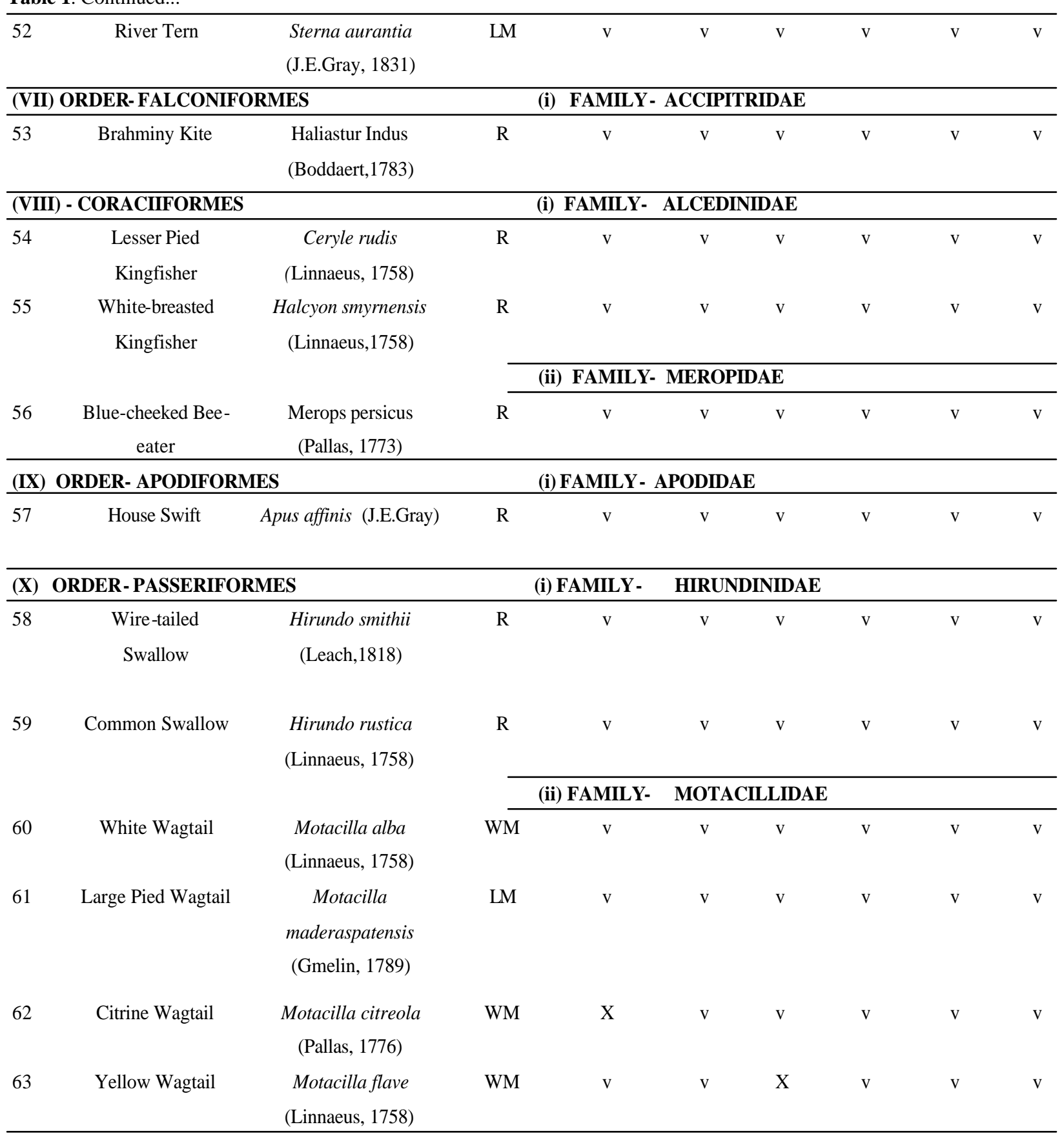

*Abbreviation : GHU-Ghula; KTH- Kaithal;KAL- Kalayat; PUN-Pundri; RAJ-Rajound; SIW- Siwan; Res. Status- Residential Status, WM- Winter Migratory, LM- Local Migratory, SM- Summer Migratory and R- Resident

the selected rural village ponds of Kaithal District in Haryana. Out of 270 villages in District Kaithal, about 90 villages were visited atleast once during the study area. In these villages about 90 rural ponds were selected for survey of wetland birds, focusing attention on migratory birds. Visits were made so as to cover the entire period of sun-shine during any single visit. Evidences were collected with the help of Zenith Camera with Russian made telelens. The various wetland birds seen during the study period were further segregated according to their residential status categories like: "Resident"; "Winter Migratory"; "Local Migratory" and "Summer Migratory" by following the technique developed by Kumar et al, 2005. Identification of birds observed during the study period was done with the help of literature, Ali, 1996; Ali and Ripley, 2001; Grewal et al, 2003; Grimmet et al., 1998; Inskipp et al,1999;Alfred et al, 2001; Besten, 2004 and Kumar etal., 2005; and consultation with experts 


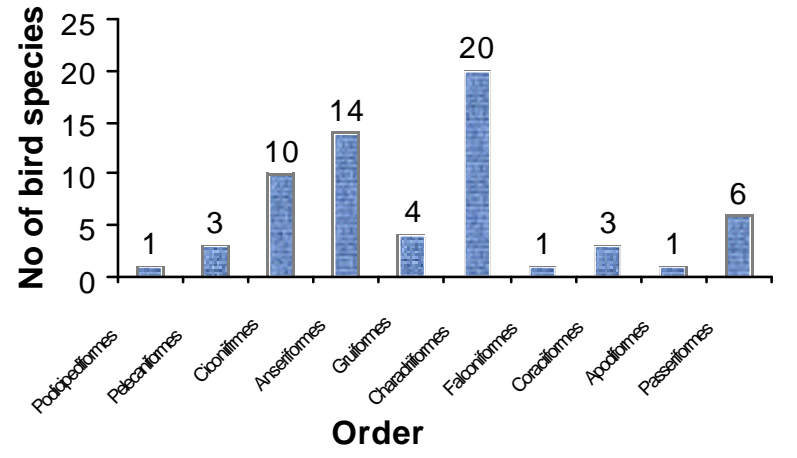

Fig.1. Depiction of incidence of wetland birds observed at village ponds in Kaithal District during 2005-08.

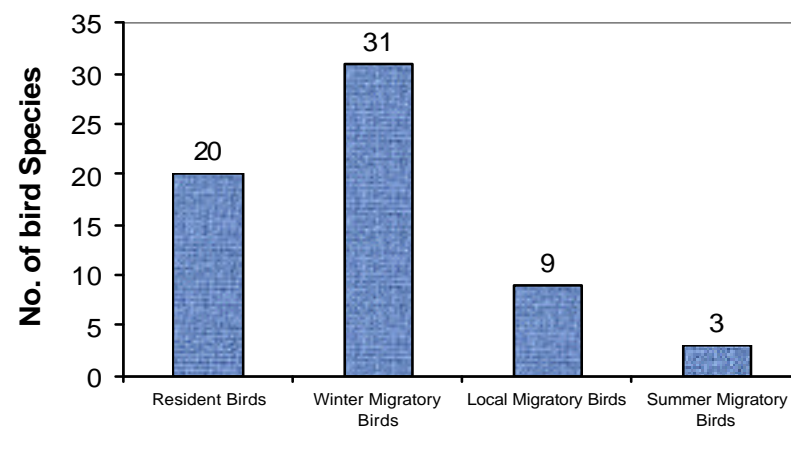

Residential Status

Fig.2. Showing the number of Resident, Winter Migratory, Local Migratory and Summer Migratory birds observed in Kaithal District during 2005-08.

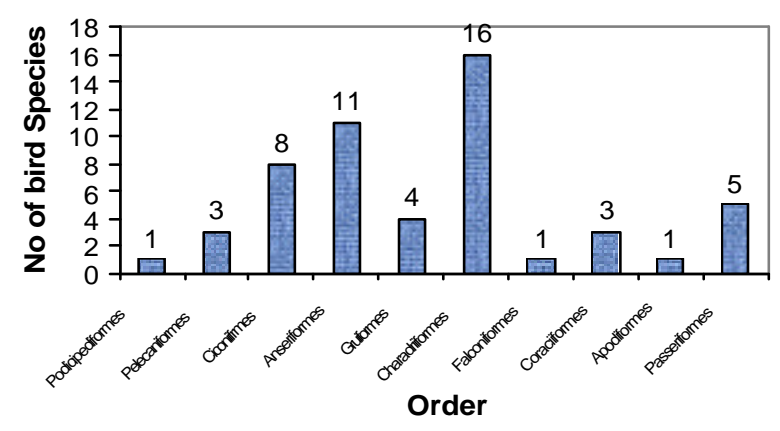

Fig. 3

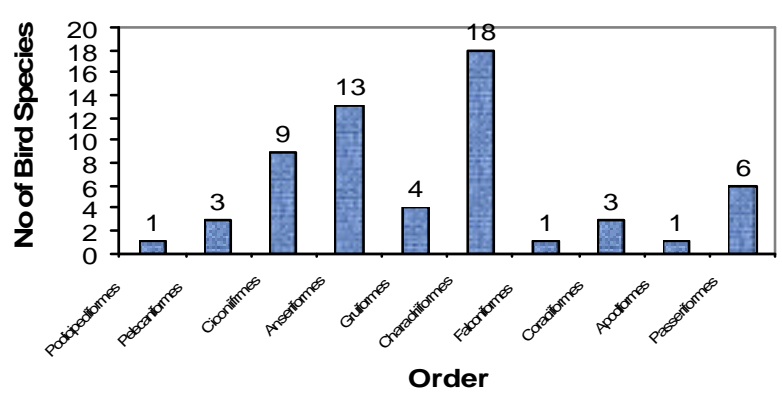

Fig. 4

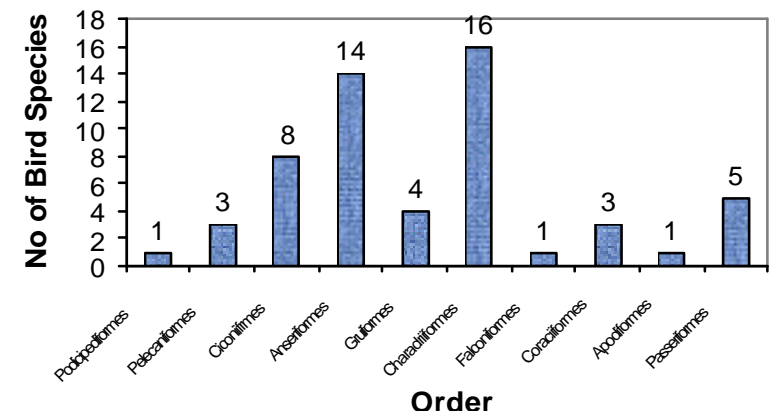

Fig. 5

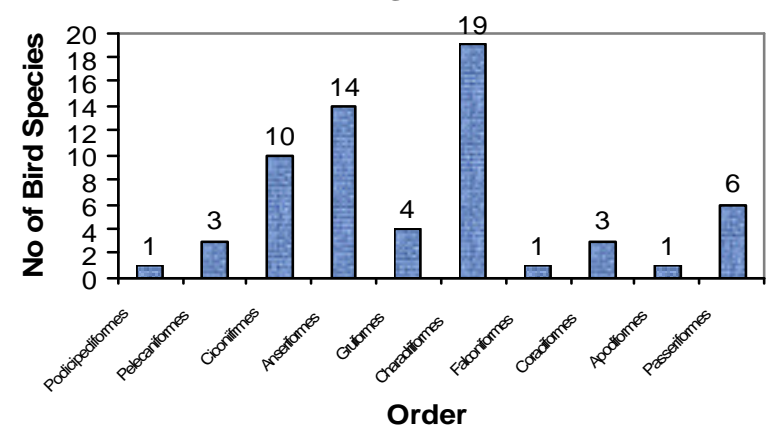

Fig. 6

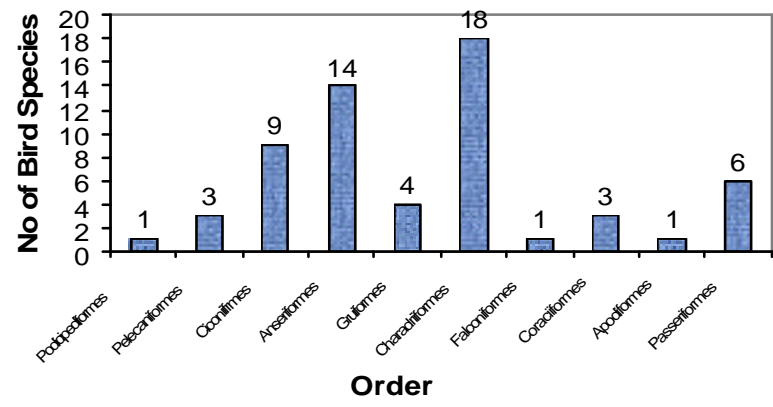

Fig. 7

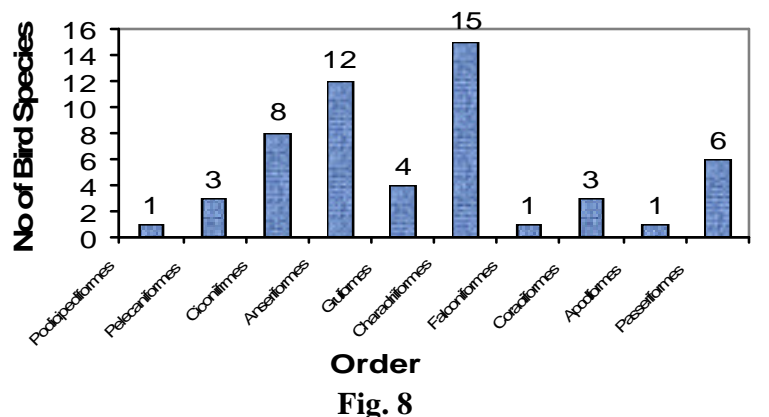

Figs. 3-8. Depiction of incidence of wetland birds observed at village ponds of Ghula, Kaithal, Kalayat, Pundri, Rajound and Siwan Blocks respectively during 2005-08.

\section{RESULTS AND DISCUSSION}

During the three years of study in Kaithal District in Haryana in respect of wetland birds available in rural ponds, it is evident from Table 1 that in all only 63 species could be recorded. Gupta et al. (2009) have reported 72 
wetland birds from Karnal district in Haryana. Similarly, other worker like Pasha et al., (2004) observed 262 species of birds in Pench Tiger Reserve, Madhya Pradesh. Out of these, 162 were residents, 70 winter visitors, 3 summer visitors, 25 local migrants and 2 were vagrant species. Rahmani (1991) reported 258 species of birds while working on Karera Bustard Sanctuary, Madhya Pradesh. Out of these 258 species, 86 were migrants.

Further, Khan (2005) reported a total of 198 species of birds from which 134 are resident and 64 were migrants from Sundarbans East Wildlife Sanctuary, Bangladesh. Also, Kumar and Sivaperuman (2005) observed a total of 149 species of birds belonging to 17 orders and 53 families from the National park. Out of these, 121 were resident and 28 migrants. Kalsi (1998) reported 161 species of birds, out of which, 112 were resident and 49 were migrant species from Kalesar Wildlife Sanctuary, Haryana. Further, these 63 species of wetland birds observed in village ponds of Kaithal district could be segregated into 10 orders and 16 families (Table 1).

It is evident from Fig. 1 that maximum wetland birds belong to Order Charadriiformes (20 species) followed by Anseriformes (14 species), Ciconiiformes (10 species) and Passeriformes (06 species). The least avian diversity is observed in case of Orders Falconiformes, Apodiformes and Podicipediformes (One species each). The incidence of wetland birds in Blockwise manner is depicted in Fig. 3 (Guhla Block); Fig.4 (Kaithal Block); Fig.5 (Kalayat Block); Fig.6 (Pundri Block); Fig.7 (Rajound Block); Fig.8 (Siwan Block).The diversity of birds in these is more or less similar (Fig.3-8), thereby proving the similarity of wetland avifauna in Kaithal District. However, Pundri Block has shown Spotted Greenshank which is peculiar in having this species and was not observed in other blocks.

Considering any single family demonstrating highest diversity, it is family Anatidae of Order Anseriformes (14 species) followed by Scolopacidae (10 species) and Ardeidae (8 species). On the other hand, family Podicipedidae of Order Podicipediformes is represented by just one species (Little Grebe), as also, in case of Accipitridae i.e. Brahminy Kite.(Table.1)

Further as per Kumar et al, 2005 categories like Resident birds, Winter Migratory Birds, Local Migratory Birds and Summer Migratory could be identified, maximum being Winter Migratory (31 Species) followed by Resident (20 species), local Migratory (9 species) and Summer Migratory (3 species) (Fig. 2)

In conclusion, 63 species of wetland birds could be spotted in Kaithal District in Haryana state during the three years of study (2005-08) in rural ponds precincts. Gupta et al (2009) have reported 72 species of birds in a nearby District of Karnal during the same period of study proving thereby that almost same spectrum of wetland birds is reflected in Karnal and Kaithal district in Haryana.

\section{ACKNOWLEDGEMENTS}

The authors are grateful to authorities of Kurukshetra University including Chairman, Department of Zoology for providing the necessary facilities required for this study. Dr. Tirshem Kaushik is highly thankful to Prof. Prem Kumari Gupta, I.G.N. College, Ladwa for encouraging throughout the study period.

\section{REFERENCES}

Abdulali. H. (1955). Attachment to winter quarters in migratory birds. J. Bombay Nat. Hist. Soc., 53(2):265.

Aitkin, E.H. (1891). The migration of birds. J. Bombay Nat. Hist. Soc., 6(2):268-270.

Alfred, J. R. B, Kumar, A., Tak, P. C. and Sati, J.P. (2001). Waterbirds of northern India. Rec. Zool. Surv. India, Occ. Paper No. 190: i-xxiv, 1-227.

Ali, S. and Ripley, S. D. (1968). Handbook of the birds of India and Pakistan together with those of Nepal, Sikkim, Bhutan and Ceylon. 1 Vols. Oxford University Press. New Delhi.

Ali, S. and Ripley, S. D. (2001). Handbook of the birds of India and Pakistan together with those of Bangladesh, Nepal, Bhutan and Sri Lanka. 10 Vols. Oxford University Press. New Delhi.

Ali, S. (1996). The Book of Indian Birds. 12 $2^{\text {th }}$ Edition (Revised \& enlarged), Oxford University Press, Mumbai.

Bailey, R.S. (1971). Sea bird observation off Somalia. Ibis, 113: 29- 41.

Bairlein, F. (2003). The study of bird migrations- some future perspectives. Bird study, 50:243-253

Besten, J.W.D. (2004). Birds of Kangra. Moonpeak Publisher, Pp. 173.

Birdlife International (2001). Threatened Birds of Asia: Birdlife International Red Data Book. Cambridge, U.K: Birdlife International, 3026pp.

Bisbet, I.C.T. (1963). Weight loss during migration, part-I. Bird-Banding, 34:139-159.

Bodenstein,G. and Schuz,E.(1944).Vom shleitenzug des Prachttauchers Colymbus arcticus) ornithologysche montsberichte, 52:98-105.

Collman. J. R. and Croxall, J.P. (1967).Spring migration at the Bosphorus. Ibis, 109: 359 - 372.

Dewar, D. (1908). Local bird migration in India. J. Bombay nat. Hist. Soc., 18(2):343-356.

Donald, C.H. (1952).Bird migration across the Himalayas. $J$. Bombay Nat. Hist. Soc., 51 (1): 269-271.

Drisscoll, R.V. and Ueta, M. (2002). The migration route and behavior of Eastern Curlews Numenjus madagascariensis. Ibis, 144(3):E119-E130.

Feeny, P.P., Arnold, R.W and Railey, R. S. (1968). Autumn migration in the south Caspian region. Ibis, 110: 35-86

Gandhi, S. S. and S.K. Singh (1995). Avifauna of Asan Barrage. Cheetal, 34(1): 29-34.

Grewal. B., Harvey, B. and Pfister, P. (2003). A Photographic Guide to the Birds of the Indian subcontinents. Singapore, APA Publication.

Grimmet, R., Inskipp, T. and Inskipp, C. (1998). Birds of the 
Indian subcontinent. Oxford University Press, Delhi, 888pp. Gupta, R. C. and Bajaj, M. (1997). Preliminary investigations into the migratory birds of Braham Sarovar at Kurukshetra. Jeevanti, 15:29-41.

Gutpa, R. C. and Bajaj, M. (1998). Preliminary observations on winter avifauna of a perennial sewer wetland body of Kurukshetra. Jeevanti, 16: 46-57.

Gupta, R. C. and Bajaj, M. (1999). An analysis of Ecological and behavioral patterns of migratory Shoveller (Anas clypeata) (Linnaeus) in certain wetlands of Haryana. Jeevanti, 17: 27-35.

Gutpa, R. C. and Bajaj, M. (2000). Preliminary observation on a rare lapwing species, White- tailed, (Vanellus leucurus) (Lichtenstein). J. NATCON, 12(2): 197-203.

Gupta,R. C. and Kumar,S. (2009). Determination of avian bio diversity in Morni hills in district Panchkula, Haryana. $J$. Adv. Zool., 2009: 30 (1):44-53.

Gupta,R. C., Kaushik, T.K. and Kumar, S.(2009).Analysis of Winter migratory Wetland Birds in Karnal district in Haryana. J. Adv. Zool., 2009: 30 (2):104-117.

Hartley, P. H. T. (1949). The biology of the Mourning Chat in winter Quarters. Ibis, 91:393-413.

Inskipp, C., Inskipp, T. and Grimmet, R. (1999). Pocket guide to the Birds of Indian Subcontinent. Oxford University Press.

Javed, S., Higuchi, H., Nagendran, M. and Takekawa, J. Y. (2003). Satelllite Telemetry and Wildlife studies in India: Advantages, options and challenges. Curr. Sci., 85(10) 14391443.

Kalsi, R.S. (1998). Birds of Kalesar Wild Life Sanctuary, Haryana, India Forktail, 13: 29-32.

Khacher, L. J. (1986). Duck migration across the Himalaya Tufted Duck Aythya fuligula at 13,700'on Rohtang Pass, Himachal Pradesh. J. Bombay Nat. Hist. Soc., 83 (Suppl.): 199-200.

Khan, M.A. (2002). Avifauna of Kughan Valley, North West Frontier province, Pakistan. Tiger Paper, 29(3): 16-19.

Krishna Raju, K.S.R. (1978). Ecological notes on some migrants in India. J. Bombay Nat. Hist. Soc., 75: 1080-1089.

Kumar, A., Sati, J.P., Tak, P.C. and Alfred, J.R.B. (2005). Handbook on Indian Wetland Birds and their Conservation: i-xxvi; 1-468 (Published by Director, Zool. Surv. India).

Kumar, S. and Sivaperuman, C. (2005). Bird Community structure in Ranthombhore National Park. Tiger Paper, 32(2): 16-24.
Lasiewski, R.C. (1962). The energetics of migrating humming birds. Condor, 64:324.

Lincoln, F.C. (1950). Migration of Birds. U.S. Fish and Wildlife Service, Circular No.16, Washington, D.C.

Lucca, C.D. (1969). Bird migration over the Maltese Islands. Ibis, 111: 322-336.

McClure, H.E. (1974). Arrival and departure of migratory birds at Keoladeo National Park, Bharatpur J. Bombay Nat. Hist. Soc., 71:31-34.

Mohapatra, K. K. and Rao, P. (1994). Winter migrants seen at Pulicat Bird Sanctuary and neighboring hills. Forktail, 16: 101-123.

Pandey, S. (1989). The Pong Dam Lake Bird Sanctuary, Himachal Pradesh. Newsletter for Birdwatchers, $29(7 \& 8)$ : 3-4.

Pasha, M.K.S, Jaypal, R., Areendran, G., Qureshi, Q., and Sankar, K. (2004). Birds of Pench Tiger Reserve, Madhya Pradesh, Central India. Newsletter for ornithologists, 1(12): 2-8.

Pennycuick, C.J. (1969). The mechanics of bird migration. Ibis, 111: 525-555

Prater, S.H. (1931): The migration of White Stork. J. Bombay Nat. Hist. Soc., 35(2): 459.

Rahmani, A.R. (1991). Birds of the Karera Bustard Sanctuary, Madhya Pradesh. J. Bombay Nat. Hist. Soc., 88: 170 -194.

Ram, L. (1978). Bird migration in Suraha Lake, Ballia, U.P. Cheetal, 20(1): 23-25.

Rowan,W. (1929). Experiment in bird migration, manipulation of the reproductive cycle: seasonal histological changes in the gonads. Proceeding of the Boston society of Natural History, 39:151-208.

Sharma, V. and Pandey, S. (1989). Pheasant surveys in the Shimla Hills of Himachal Pradesh, India.The World Pheasant Association Journal, 14: 64-78.

Singh, A. P. (2000). Birds of the lower Garhwal Himalayas: Dehra Dun valley and Sriharikota Island during 1989-90 and 1990-91 seasons. Mayura, (11): 9-11.

Stressmann, E. (1927-1934). In Kukenthal, W. and Krumbach, T. Handbuchder Zoologic. Sauropsida. Aves W.de Gruyter and Co., Berlin and Leipzig.

Tak, P. C., Padiwal, R. and Sharma, R.M. (2001). Occurrence of huge wintering population of Bar-headed Goose, Anser indicus, at Pong Dam Wetland, Himachal Pradesh. Bionotes, 5(4): $88-89$. 